\title{
The Risk of Thrombocytopenia During Valproic Acid Therapy: A Critical Summary of Available Clinical Data
}

\author{
Massimiliano Buoli $^{1}\left(\right.$ Marta Serati $^{1} \cdot$ Andrea Botturi $^{1,2} \cdot$ A. Carlo Altamura $^{1}$
}

Published online: 19 December 2017

(C) The Author(s) 2017. This article is an open access publication

\begin{abstract}
Valproate is an effective anti-epileptic and mood stabilizer drug, but its prescription may be complicated by the development of thrombocytopenia. The purpose of the present manuscript is to provide a critical overview about the risk of thrombocytopenia during treatment with valproate. A search of the main database sources has been conducted to identify relevant papers about the topic. In the studies with a larger sample size ( $>150$ subjects), thrombocytopenia occurred in $12-18 \%$ of subjects receiving treatment with valproate. Advanced age, female gender, and high doses were found to be risk factors for the development of thrombocytopenia during treatment with valproate. Future research is needed to clarify the clinical impact of the occurrence of thrombocytopenia during valproate treatment (e.g., the risk of life-threatening events such as stroke or the development of thrombocytopenia during short- versus long-term administration, or oral versus intravenous formulations).
\end{abstract}

Massimiliano Buoli

massimiliano.buoli@unimi.it

1 Department of Psychiatry, Fondazione IRCCS Ca' Granda Ospedale Maggiore Policlinico, University of Milan, Via F. Sforza 35, 20122 Milan, Italy

2 Fondazione IRCCS Istituto Neurologico Carlo Besta, Milan, Italy

\section{Key Points}

Treatment with valproic acid (VPA), despite its efficacy in bipolar disorder and epilepsy, may be associated with thrombocytopenia.

The risk factors for VPA-associated thrombocytopenia include female gender, advanced age, and high doses.

Future research should define the clinical impact of VPA-associated thrombocytopenia (e.g., the risk of hemorrhagic stroke during VPA treatment).

\section{Introduction}

Valproic acid (VPA) was synthesized by the American chemist Beverly S. Burton more than a century ago as a derivative of valeric acid, a component of the herbal medicine Valeriana officinalis. It was mainly used as a solvent for organic compounds until 1963, when Pierre Eymard discovered that all solutions containing valproate had anticonvulsant properties [1]. Rapidly, VPA came into regular clinical usage in France (late 1960s) as well as in the UK (1972) and the US (1978). Currently, VPA is widely prescribed as an antiepileptic drug and mood stabilizer. Its effectiveness in bipolar disorder (BD) was firstly demonstrated by Lambert and colleagues in 1966 [1], and now international guidelines recommend its use for acute and long-term treatment of BD [2]. Of note, VPA monotherapy has showed the same effectiveness as lithium 
and atypical antipsychotics for the treatment of acute mania, but with a better tolerability [2]. VPA can be currently considered as the first-line option for almost all epileptic syndromes (focal seizures with or without secondary generalization), including childhood ones.

Despite its long-standing usage, the mechanism of action of VPA is still debated. Studies originally focused on its ability to dampen neuronal hyper-excitability by potentiating the inhibition of neurotransmission, as a result of its chemical similarity to gamma-aminobutyric acid (GABA). More recently, some research has shown further pharmacodynamic properties of the compound, including a direct effect on voltage-gated sodium channels or the disruption of the membrane environment of sodium channels [3]. VPA also appears to regulate the excitatory activity of NMDA glutamate receptors and modulates the epigenetic regulation of neuronal gene expression by non-selective inhibition of histone deacetylase [1].

Common side effects of VPA include fatigue, tremor, sedation, gastrointestinal symptoms, and weight gain; these side effects are mostly dose or serum concentration dependent and can be minimized by dosage modification. The teratogenic risks of the compound are well documented in the literature. VPA adverse reactions can be classified as neurological, metabolic, endocrine, and hematological ones. We decided to focus on thrombocytopenia because this side effect often goes unnoticed and can suddenly manifest with life-threatening events such as hemorrhagic stroke [4]. The purpose of the present manuscript is therefore to provide a critical overview about the risk of thrombocytopenia in subjects treated with VPA. To our knowledge, there are no recent comprehensive reviews about this specific topic. From a statistical point of view, thrombocytopenia is defined as a platelet count of $<150,000$ per microliter (the 2.5th lower percentile); however, emergency treatment is required in case of a count $<50,000$ per microliter. In some research, a more restricted definition of thrombocytopenia is used: a platelet count of $<100,000$ or 130,000 per microliter.

\section{Methods}

A careful search of articles on MEDLINE, PsycINFO, Isi Web of Knowledge, and Medscape was performed by matching the words 'valproate' and 'valproic acid' with 'thrombocytopenia'. After excluding duplicates, 159 abstracts were screened. Nine papers were finally considered after excluding off-topic research (e.g., about VPA efficacy on mood symptoms or epilepsy), case reports and case series, and articles with pediatric populations. Children were excluded because they are thought to have a different risk of thrombocytopenia as a consequence of pharmacological treatment [5]. Only papers from the last 30 years (1987-2017) were included as available information was not always accurate in most of the previous articles.

\section{Results}

It is currently known that thrombocytopenia can occur in $5-18 \%$ of patients taking VPA [6,7], and is more frequently observed in women and elderly subjects [8-10]. Moreover, a lower baseline platelet count is reported to be an additional risk factor for thrombocytopenia, and VPA dose influences the final platelet count in a proportional way [11-13].

The exact mechanism through which valproate can cause thrombocytopenia is unknown; it can be caused by an increased disruption of platelets as well as by the formation of autoantibodies destroying platelets or by decreased production due to a direct toxic effect on bone marrow [3]. Laboratory studies have shown that VPA perturbs hematopoietic homeostasis through erythroid differentiation inhibition and activation of the myelo-monocytic pathway [3]. The most frequent clinical manifestations of thrombocytopenia are represented by prolonged bleeding time, abnormality in laboratory platelet tests, or petechial bleeding [3].

In a sample of epileptic subjects, May and Sunder [14] reported thrombocytopenia to be the most frequent adverse event; nevertheless, hematologic toxicity was never severe enough to discontinue therapy and it always improved after small decrements of VPA doses. In Italy, a survey on the safety profile of antiepileptic drugs reported that the highest percentage of hematological reactions (including thrombocytopenia) was related to VPA [15]. A study with a sample of 126 adult psychiatric patients reported a $5 \%$ prevalence of thrombocytopenia $(<150,000 / \mu \mathrm{L})$ with a significant increased risk in female subjects in case of serum concentrations $>80 \mu \mathrm{g} / \mathrm{mL}$; moreover, every $10 \mu \mathrm{g} /$ $\mathrm{mL}$ increase in serum drug levels was associated with a decrease of 17 units $/ \mu \mathrm{L}$ in the platelet count [6]. Another survey with 264 psychiatric patients reported a 12\% prevalence of thrombocytopenia, with the elderly having the highest risk, especially with a VPA dosage $>1 \mathrm{~g} /$ day [9]. Trannel and colleagues [8] confirmed in a small sample of 39 psychiatric patients that elderly patients experienced thrombocytopenia more frequently than younger ones during VPA treatment (54 vs 13\%). In addition, Nasreddine and Beydoun [10] reported that about $17.7 \%$ of epileptic patients experience at least one episode of thrombocytopenia during VPA treatment, and the risk was significantly increased in case of VPA plasma levels $>100 \mu \mathrm{g} /$ $\mathrm{mL}$ for women and $130 \mu \mathrm{g} / \mathrm{mL}$ for men. Finally, a recent 
Table 1 Valproic acid monotherapy and thrombocytopenia: summary of findings

\begin{tabular}{|c|c|c|c|c|c|c|c|}
\hline Authors & $\begin{array}{l}\text { Quality } \\
\text { rating }\end{array}$ & $\begin{array}{l}\text { Sample } \\
\text { size }\end{array}$ & Study design & Disorder & Primary objective & $\begin{array}{l}\text { Valproate } \\
\text { plasma level } \\
(\mu \mathrm{g} / \mathrm{mL})\end{array}$ & $\begin{array}{l}\text { Rate of } \\
\text { thrombocytopenia } \\
(<150,000 / \mu \mathrm{L})\end{array}$ \\
\hline May and Sunder [14] & 2 & 60 & $\begin{array}{l}\text { Prospective study. } \\
\text { Hematologists were } \\
\text { blinded with respect } \\
\text { to patients' treatment }\end{array}$ & Epilepsy & $\begin{array}{l}\text { Rate of hematologic } \\
\text { side effects during } \\
\text { VPA treatment }\end{array}$ & $30-145$ & $\begin{array}{l}20 \% \\
\quad \text { (thrombocytopenia } \\
\quad<130,000 / \mu \mathrm{L})\end{array}$ \\
\hline Gidal et al. [11] & 2 & 27 & $\begin{array}{l}\text { Prospective, controlled } \\
\text { study }\end{array}$ & Epilepsy & $\begin{array}{l}\text { Rate of } \\
\text { thrombocytopenia } \\
\text { during VPA } \\
\text { treatment }\end{array}$ & NA & NA \\
\hline Conley et al. [9] ${ }^{\mathrm{a}}$ & 3 & 264 & Retrospective & $\begin{array}{l}\text { Psychiatric } \\
\text { patients }\end{array}$ & $\begin{array}{l}\text { Prevalence of } \\
\text { thrombocytopenia in } \\
\text { hospitalized patients } \\
\text { receiving VPA }\end{array}$ & NA & $12 \%$ \\
\hline Trannel et al. [8] & 3 & 39 & Retrospective & $\begin{array}{l}\text { Psychiatric } \\
\text { inpatients }\end{array}$ & $\begin{array}{l}\text { Prevalence of } \\
\text { thrombocytopenia in } \\
\text { hospitalized patients } \\
\text { receiving VPA }\end{array}$ & $16-161$ & $\begin{array}{l}28 \% \text { (total sample) } \\
54 \% \text { (elderly } \\
\text { patients) } \\
\text { (thrombocytopenia } \\
\quad<100,000 / \mu \mathrm{L} \text { ) }\end{array}$ \\
\hline De Berardis et al. [13] & 2 & 25 & $\begin{array}{l}\text { Prospective, controlled } \\
\text { study }\end{array}$ & $\begin{array}{l}\text { New onset } \\
\text { bipolar } \\
\text { patients }\end{array}$ & $\begin{array}{l}\text { Rate of } \\
\text { thrombocytopenia } \\
\text { during VPA } \\
\text { treatment }\end{array}$ & $61^{\mathrm{b}}$ & $0 \%^{\mathrm{d}}$ \\
\hline $\begin{array}{r}\text { Nasreddine and } \\
\text { Beydoun [10] }\end{array}$ & 1 & 265 & $\begin{array}{l}\text { Double-blind, } \\
\text { multicenter, } \\
\text { prospective study }\end{array}$ & $\begin{array}{l}\text { Refractory } \\
\text { partial } \\
\text { epilepsy }\end{array}$ & $\begin{array}{l}\text { The evaluation of the } \\
\text { relationship between } \\
\text { VPA plasma levels } \\
\text { and platelet counts }\end{array}$ & $\begin{array}{l}\text { 13-257 } \\
\text { Increased risk } \\
>100 \text { for } \\
\text { women and } \\
>130 \text { for } \\
\text { men }\end{array}$ & $\begin{array}{l}18 \% \\
\quad \text { (thrombocytopenia } \\
\quad<100,000 / \mu \mathrm{L})\end{array}$ \\
\hline $\begin{array}{l}\text { Vasudev et al. [6] (no } \\
\text { information about } \\
\text { concomitant } \\
\text { medication alongside } \\
\text { VPA) }\end{array}$ & 3 & 126 & Retrospective & $\begin{array}{l}\text { Psychiatric } \\
\text { patients }\end{array}$ & $\begin{array}{l}\text { Rate of Hematologic } \\
\text { side effects during } \\
\text { VPA treatment }\end{array}$ & $\begin{array}{l}11-138 \\
\text { Increased risk } \\
\quad>80\end{array}$ & $5 \%$ \\
\hline $\begin{array}{l}\text { Martínez-Lazcano } \\
\text { et al. [7] } \\
\text { (concomitant } \\
\text { psychiatric } \\
\text { medication as well as } \\
\text { VPA) }\end{array}$ & 3 & 167 & Cross-sectional & $\begin{array}{l}\text { Psychiatric } \\
\text { patients }\end{array}$ & $\begin{array}{l}\text { Frequency of use of } \\
\text { VPA in psychiatric } \\
\text { patients and rate of } \\
\text { relative side effects }\end{array}$ & $72^{\mathrm{b}}$ & $18 \%$ \\
\hline Zighetti et al. [16] & 3 & $\begin{array}{l}20 \text { cases, } \\
20 \\
\text { controls }\end{array}$ & Cross-sectional & Epilepsy & $\begin{array}{l}\text { Measurement of } \\
\text { parameters of } \\
\text { primary hemostasis } \\
\text { in VPA-treated } \\
\text { patients }\end{array}$ & $67^{c}$ & $\begin{array}{l}10 \% \text { cases (subjects } \\
\text { treated with VPA) } \\
20 \% \text { controls } \\
\text { (healthy subjects } \\
\text { or treated with a } \\
\text { different } \\
\text { antiepileptic) }\end{array}$ \\
\hline
\end{tabular}

Quality rating was performed according to the following criteria (Qualitative Assessment Tool for Quantitative Studies): (i) selection bias (sample size power and number of subjects who agreed to participate into the study); (ii) study design (randomized versus non-randomized trials); (iii) confounders (yes/no); (iv) blinding (yes/no); (v) data collection methods (self-reported data, observations by investigators or medical records); (vi) presence of description of numbers and reasons for withdrawals and drop-outs. $1=$ strong (no weak ratings according to above criteria); $2=$ moderate (one weak rating according to above criteria); 3 = weak (two or more weak ratings according to above criteria)

NA not available, VPA valproic acid

${ }^{a}$ In this study, patients received polytherapy (valproate plus antidepressants, clozapine, donepezil, aspirin, carbamazepine, heparin, ticlopidine, trimethoprim-sulfamethoxazole). Among patients in treatment with valproate, subjects with thrombocytopenia more frequently received concomitant treatment with aspirin and donepezil

${ }^{\mathrm{b}}$ Mean plasma concentrations ( $\left.\mathrm{SD} \pm 20\right)$

${ }^{\mathrm{c}}$ Mean plasma concentrations $(\mathrm{SD} \pm 38)$

${ }^{\mathrm{d}}$ Significant decrease of platelet count in bipolar subjects in treatment with valproate than in healthy controls 
study by Zighetti and colleagues [16] failed to find a significant association between chronic VPA treatment and risk of abnormal hemostasis or thrombocytopenia (Table 1).

\section{Conclusions}

VPA is currently considered a first-line treatment option for the management of both BD and different forms of epilepsy in the light of its efficacy and relative safety. More than 40 years of clinical experience have clearly established the common adverse events associated with VPA, including hepatotoxicity and the teratogenic risks. It is very surprising that thrombocytopenia, although considered a common/very common side effect according to the definition by the World Health Organization, has attracted less interest in clinical research despite the important therapeutic implications. Of note, the available data report a prevalence of thrombocytopenia between $5-54 \%$ of total patients receiving treatment with VPA (12-18\% in studies with a sample size $>150$ ). The risk factors of VPA-associated thrombocytopenia appear to be advanced age, female gender, and high doses, so clinicians should be particularly cautious in prescribing this compound in elderly female patients, especially in doses $>1 \mathrm{~g} /$ day. It should also be remembered that elderly patients frequently receive multiple therapies that can increase the risk of thrombocytopenia or bleeding (e.g., aspirin or anticoagulants frequently prescribed to the geriatric population). Adjustment of doses seems to partially reverse VPA-associated thrombocytopenia.

Future research should address a number of questions. First, the real clinical risks of VPA-associated thrombocytopenia are unclear; for example, it is not defined whether VPA-associated thrombocytopenia is really associated with an increased risk of life-threatening adverse events such as hemorrhagic stroke. Second, although one study demonstrated similar pharmacokinetic parameters in epileptic and psychiatric patients in the course of VPA therapy [17], the type of illness may influence the risk of adverse events associated with thrombocytopenia. Patients with BD, independently from treatment with atypical antipsychotics, have a higher frequency of diabetes and metabolic syndrome than the general population [2], so treatment with VPA may expose bipolar subjects to a further risk of cardiovascular events as a result of thrombocytopenia. Furthermore, patients with a psychiatric disorder are frequently treated with multiple therapies which may increase the risk of bleeding (e.g., selective serotonin reuptake inhibitors). Third, it is not entirely clear how soon hematological abnormalities may appear, so that short-term therapy (such as during a manic episode) may have a limited effect compared with chronic prophylaxis [14]. Also, a different pharmacological formulation (intravenous versus oral) may impact differently on the risk of thrombocytopenia. Finally, the exact mechanism of valproateassociated thrombocytopenia should be clarified with the aim to carry out preventive strategies for this adverse event as well as to identify high-risk populations.

Author Contributions Dr. Buoli wrote the paper and dealt with the methods. Drs. Serati and Botturi contributed to writing the paper and conducting the initial article research. Prof. Altamura supervised the research.

Funding This work did not receive funding sources.

\section{Compliance with Ethical Standards}

Conflict of interest Prof. Altamura has served as a consultant for Merck and Astra Zeneca as well as for Sanofi, Lilly, and Pfizer speaker bureaus. Dr. Buoli has served as a consultant for Lundbeck. Drs. Serati and Botturi do not have any affiliation with or financial interest in any organization that might pose a conflict of interest with the present article. No funding sources were received for the preparation of the present manuscript.

Open Access This article is distributed under the terms of the Creative Commons Attribution-NonCommercial 4.0 International License (http://creativecommons.org/licenses/by-nc/4.0/), which permits any noncommercial use, distribution, and reproduction in any medium, provided you give appropriate credit to the original author(s) and the source, provide a link to the Creative Commons license, and indicate if changes were made.

\section{References}

1. Tomson T, Battino D, Perucca E. The remarkable story of valproic acid. Lancet Neurol. 2016;15:141.

2. Fountoulakis KN, Grunze H, Vieta E, Young A, Yatham L, Blier $\mathrm{P}$, Kasper S, Moeller HJ. The International College of NeuroPsychopharmacology (CINP) treatment guidelines for Bipolar disorder in adults (CINP-BD-2017), part 3: the clinical guidelines. Int J Neuropsychopharmacol. 2016;20:180-95.

3. Verrotti A, Scaparrotta A, Grosso S, Chiarelli F, Coppola G. Anticonvulsant drugs and hematological disease. Neurol Sci. 2014;35:983-93.

4. Quinones-Hinojosa A, Gulati M, Singh V, Lawton MT. Spontaneous intracerebral hemorrhage due to coagulation disorders. Neurosurg Focus. 2003;15:E3.

5. Allarakhia IN, Garofalo EA, Komarynski MA, Robertson PL. Valproic acid and thrombocytopenia in children: a case-controlled retrospective study. Pediatr Neurol. 1996;14:303-7.

6. Vasudev K, Keown P, Gibb I, McAllister-Williams RH. Hematological effects of valproate in psychiatric patients what are the risk factors? J Clin Psychopharmacol. 2010;30:282-5.

7. Martínez-Lazcano MT, Esplá-González S, Herraiz-Robles P, Hernández-Pérez P, Chillerón-Cuenca R, Pol-Yanguas E. Use of valproic acid in long stay units of psychiatry. Farm Hosp. 2015;39:92-101. 
8. Trannel TJ, Ahmed I, Goebert D. Occurrence of thrombocytopenia in psychiatric patients taking valproate. Am J Psychiatry. 2001;158:128-30.

9. Conley EL, Coley KC, Pollock BG, Dapos SV, Maxwell R, Branch RA. Prevalence and risk of thrombocytopenia with valproic acid: experience at a psychiatric teaching hospital. Pharmacotherapy. 2001;21:1325-30.

10. Nasreddine W, Beydoun A. Valproate-induced thrombocytopenia: a prospective monotherapy study. Epilepsia. 2008;49:438-45.

11. Gidal B, Spencer N, Maly M, Pitterle M, Williams E, Collins M, Jones J. Valproate-mediated disturbances of hemostasis: relationship to dose and plasma concentration. Neurology. 1994;44:1418-22.

12. Kaufman KR, Gerner R. Dose-dependent valproic acid thrombocytopenia in bipolar disorder. Ann Clin Psychiatry. 1998;10:35-7.
13. De Berardis D, Campanella D, Matera V, Gambi F, La Rovere R, Sepede G, Grimaldi MR, Pacilli AM, Salerno RM, Ferro FM. Thrombocytopenia during valproic acid treatment in young patients with new-onset bipolar disorder. J Clin Psychopharmacol. 2003;23:451-8.

14. May RB, Sunder TR. Hematologic manifestations of long-term valproate therapy. Epilepsia. 1993;34:1098-101.

15. Iorio ML, Moretti U, Colcera S, Magro L, Meneghelli I, Motola D, Rivolta AL, Salvo F, Velo GP. Use and safety profile of antiepileptic drugs in Italy. Eur $\mathrm{J}$ Clin Pharmacol. 2007;63:409-15.

16. Zighetti ML, Fontana G, Lussana F, Chiesa V, Vignoli A, Canevini MP, Cattaneo M. Effects of chronic administration of valproic acid to epileptic patients on coagulation tests and primary hemostasis. Epilepsia. 2015;56:e49-52.

17. Vasudev K, Das S, Goswami U, Tayal G. Pharmacokinetics of valproic acid in patients with bipolar disorder. J Psychopharmacol. 2001;15:187-90. 